DOI: 10.14526/2070-4798-2019-14-4-91-96

\title{
Physical fitness analysis in the members of special convoy units of the Federal Penitentiary Service of Russia in Perm region
}

\author{
Pavel S. Sokolov', Tatyana V. Fendel ${ }^{2 *}$ \\ ${ }^{1}$ Perm Institute of Federal Penitentiary Service \\ Perm, Russia \\ ORCIDoooo-ooo3-4868-9022,pavel.sokolov.14@mail.ru \\ ${ }^{2}$ Chaykovskiy State Institute of Physical Culture \\ Chaikovskiy, Russia \\ ORCID oooo-ooo2-6696-6102, fendel82@mail.ru*
}

\begin{abstract}
Convoy of convicts and people accused in custody has several characteristics. They determine the necessity to have a high level of their physical, psychological and professionalapplied readiness. Social, political and economic transformations in the country didn't influence the content of Physical Training Manual (PTM-2001) concerning the members of special convoy service units of Federal Penitentiary Service of Russia, which, in our opinion, has a negative influence on the level of their physical fitness. Modern life demands changes in the content of the Manual. Materials. The article presents physical fitness analysis in the members of special convoy service units of Federal Penitentiary Service of Russia in Perm region. Research methods. Information sources and normative documents analysis and summarizing, physical fitness testing, methods of mathematical statistics. Results. The results of the held research prove satisfactory level of physical fitness in the members of special convoy service units of the Federal Penitentiary Service of Russia in Perm region. We also revealed the reasons for a low effectiveness of the professional-applied physical training existing system. We offered a range of changes in the content of Physical Training Manual of the Federal Penitentiary Service (FPS) members. Conclusion. In order to increase the effectiveness of the FPS members professionalapplied physical training it is necessary to realize the search for new scientifically substantiated methodologies, including those based on intensive psycho-functional training means.
\end{abstract}

Keywords: physical training, members of penal system.

For citation: Pavel S. Sokolov, Tatyana V. Fendel*. Physical fitness analysis in the members of special convoy units of Federal Penitentiary Service of Russia in Perm region. Russian Journal of Physical Education and Sport. 2019; 14(4): 77-81. DOI: 10.14526/2070-4798-2019-14-4-91-96.

\section{INTRODUCTION}

Members of special convoy service units can't work without an effective system of their professional-applied training [2, 4].Convoy of convicts and people accused in custody has several characteristics. They determine the necessity to have a high level of their physical, psychological and professional-applied readiness. Such characteristics include the following: the restricted amount of members, which realize convoyed people security (in some cases the ratio can be one to ten); the increasing abilities of convicts and people accused in custody, for crime (escape) realization during the convoy; convicts convoy realization out of the penal system establishments; service objectives realization in terms of direct contact with civilian population $[2,3]$.

Taking into account these characteristics of the Russian Federation Ministry of Justice prepared the decree №301 on the $12^{\text {th }}$ of November, 2011, which adopted Physical Training Manual (PTM-2001). It declares the main directions of professional-applied physical training organization among the members of special convoy service units of Federal Penitentiary Service of Russia and regulates the main quantitative characteristics of this activity [1].

Social, political and economic transformations didn't influence the content of the Manual, which in our opinion, had a negative influence on the level of physical fitness of the special convoy service units Federal Penitentiary Service members of Russia.

Modern life demands urgent changes in the content of the Manual, among which are the following: 
- differentiation of demands claimed on the level of physical readiness among different categories of staff members;

- individual dynamics of achievements estimation among the staff members, taking into account their age and gender;

plans of physical training creation for different units (educational establishments of Federal Penitentiary Service of Russia, the departments of special aim, managerial staff and etc.).

Thus, the problem of searching the ways of professional-applied training effectiveness improvement in the Federal Penitentiary Service special convoy units members of Russia, is still very urgent.

\section{RESEARCH METHODS}

In order to study the existing level of physical readiness of the FPS of Russia special convoy units members in Perm region, as the starting point for further work and objectives and physical training means specification, we held a research on the basis of Federal Public Establishment Convoy Board the Main Board of Federal Penitentiary Service of Russia in Perm region.

The members of special convoy units of FPC of Russian in Perm region took part in the experiment (251 male workers).

In order to define the level of physical readiness among the members of special convoy units of FPC of Russian in Perm region we used the following control tests: 1000 meters running (min/s), 5000 meters cross running (min/s), dip up in hanging position at a high bar (quantity), shuttle running $10 x 10 \mathrm{~m}(\mathrm{~s})$. In order to define the level of power abilities development we used complex power oriented exercise ( $\mathrm{min} / \mathrm{s})$ (CPE), recommended by "Physical training Manual among the members of Penal Enforcement system". We also estimated fighting techniques use.

The final estimation of physical readiness level of the FPC special convoy unit definite member of Russia was the mean value of the marks, which he received for each of these control tests.

\section{RESULTS AND DISCUSSION}

For the received results analysis the respondents were divided into 6 age groups:

- $\quad$ the $1^{\text {st }}$ group - under 30 (114 человек / $45,4 \%$ );

the $2^{\text {nd }}$ group - from 30 till 35 (65 people / $25,9 \%$ );

the $3^{\text {rd }}$ group from 35 till 40 (36 people / $14,3 \%)$;

the $4^{\text {th }}$ group - from 40 till 45 (23 people / $9,2 \%)$;

the $5^{\text {th }}$ group - from 45 till 50 (10 people / $4,0 \%)$;

the $6^{\text {th }}$ group - from 50 and older (3 people / 1,2\%).

The results of the control exercises fulfillment by the members of the Russian FPC special convoy unit in Perm region within 2019 are presented in table 1.

Table 1 - The results of physical training control tests fulfillment by the members of the Russian FPC special convoy unit in Perm region within 2019

\begin{tabular}{|c|c|c|c|c|c|c|c|c|c|}
\hline \multirow{3}{*}{ Age group } & \multirow{3}{*}{$\begin{array}{c}\text { Total } \\
\text { number } \\
\text { of people }\end{array}$} & \multicolumn{8}{|c|}{ The final mark } \\
\hline & & \multicolumn{2}{|c|}{ « $5 »$} & \multicolumn{2}{|c|}{ «4» } & \multicolumn{2}{|c|}{ «3» } & \multicolumn{2}{|c|}{ «2» } \\
\hline & & people & $\%$ & people & $\%$ & people & $\%$ & people & $\%$ \\
\hline The $1^{\text {st }}$ group (under 30 ) & 114 & $\mathrm{O}$ & $\mathrm{O}$ & 12 & 10,53 & 80 & 70,17 & 22 & 19,3 \\
\hline $\begin{array}{c}\text { The } 2^{\text {nd }} \text { group (from } 30 \\
\text { till } 35 \text { ) }\end{array}$ & 65 & 1 & 1,54 & 13 & 20,0 & 38 & 58,46 & 13 & 20,0 \\
\hline $\begin{array}{l}\text { The } 3^{\text {rd }} \text { group (from } 35 \\
\text { till } 40 \text { ) }\end{array}$ & 36 & O & 0 & 5 & 13,89 & 30 & 83,33 & 1 & 2,78 \\
\hline $\begin{array}{l}\text { The } 4^{\text {th }} \text { group (from } 40 \\
\text { till } 45 \text { ) }\end{array}$ & 23 & 0 & 0 & 5 & 21,74 & 15 & 65,22 & 3 & 13,04 \\
\hline $\begin{array}{l}\text { The } 5^{\text {th }} \text { group (from } 45 \\
\text { till } 50 \text { ) }\end{array}$ & 10 & $\mathrm{O}$ & 0 & 3 & 30,0 & 7 & 70,0 & $\mathrm{O}$ & $\mathrm{O}$ \\
\hline $\begin{array}{c}\text { The } 6^{\text {th }} \text { group (from } 50 \\
\text { and older) }\end{array}$ & 3 & $\mathrm{O}$ & $\mathrm{O}$ & 3 & 100,0 & 0 & $\bar{O}$ & $\mathrm{O}$ & 0 \\
\hline
\end{tabular}


Almost in all age categories (except level of physical fitness among this category of people over 50 years-old) most respondents have satisfactory level of physical fitness; each $5^{\text {th }}$ respondent under 35 years-old is not able to fulfill the whole complex of control tests; only each $10^{\text {th }}$ young specialist has "good" level of physical fitness; there were no respondents with the "excellent" respondents.

The picture presents comparative characteristic of qualitative and quantitative indices of physical fitness level among the members of the Russian FPC special convoy units.

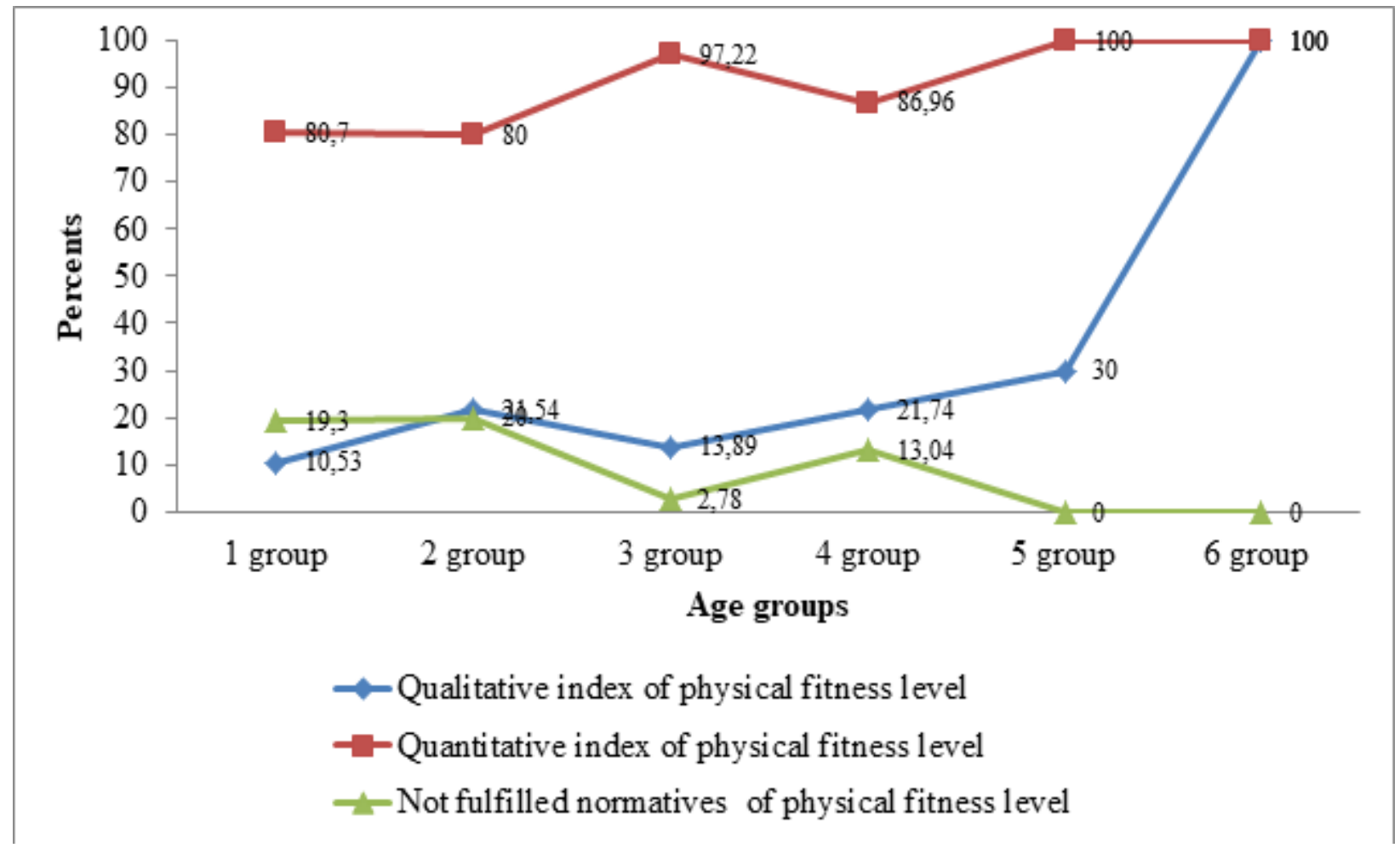

Picture - Comparative characteristics of physical fitness indices among the members of Russian FPC special convoy units in Perm region

The gap between qualitative and quantitative index of physical fitness of the members of Russia FPC special convoy units in Perm region was in all age groups, except the group of people over 50 yearsold, achieving its peak in the group of respondents at the age from 35 till 40.

Only the members of the $5^{\text {th }}$ and the $6^{\text {th }}$ groups correspond with the demands, claimed according to the level of their physical readiness.

Speaking about the separate control tests fulfillment, the mean value of sports-technical results and their average marks in each age group are presented in table 2.

Most of all qualitative results were shown in "Shuttle running $10 \times 10 \mathrm{~m}$ " test. The lowest marks were in 5000 meters cross running. Only respondents over 50 years-old managed to fulfill all control tests fundamentally.
In our opinion, the received results show low effectiveness of physical training process among the members of Russia FPC special convoy units in Perm region.

As the reasons, which caused such a result, we define the following:

- underestimation of the place and role of professional-applied physical training in the system of Russia FPC special convoy units members professional activity;

- insufficient methodical and normativejuridical support of physical training process in the Russia FPC organizations and units;

- the absence of events, which stimulate people to go in for professional-applied physical culture;

- low motivation level among staff to organize independent lessons; 
- no time, given for physical training, during the working period;

- the absence of scientifically substantiated methodologies of physical training for the Russia FPC special convoy units members;

- a low level of theoretical training of people, who are responsible for physical training of the staff and, as a rule, the absence of professional physical culture education among them;

- poor material-technical base of Penal Enforcement system establishments for professional-applied physical training realization.

Table 2 - Results of physical training control tests fulfillment by the members of Russia FPC special convoy units in Perm region within 2019

\begin{tabular}{|c|c|c|c|c|c|c|c|}
\hline \multirow{2}{*}{ Control tests } & \multirow{2}{*}{$\begin{array}{l}\text { Mean } \\
\text { values }\end{array}$} & \multicolumn{6}{|c|}{ Age groups } \\
\hline & & 1 & 2 & 3 & 4 & 5 & 6 \\
\hline \multirow{2}{*}{$1000 \mathrm{~m}$ running } & result & $3,49 \pm 0,3$ & $3,8 \pm 0,42$ & $3,8 \pm 0,37$ & $4,05 \pm 0,4$ & $4,9 \pm 0,5$ & $5,3 \pm 0,06$ \\
\hline & mark & $3,25 \pm 0,8$ & $3,22 \pm 0,7$ & $3,39 \pm 0,6$ & $3,3 \pm 0,7$ & $3,7 \pm 0,7$ & $4,0 \pm 0,2$ \\
\hline \multirow{2}{*}{$\begin{array}{l}5000 \text { m cross } \\
\text { running }\end{array}$} & result & $25,4 \pm 1,1$ & $25,7 \pm 0,8$ & $26,07 \pm 0,6$ & $26,6 \pm 0,6$ & $33,3 \pm 0,9$ & $34,1 \pm 1,1$ \\
\hline & mark & $3,15 \pm 0,6$ & $3,28 \pm 0,6$ & $3,3 \pm 0,6$ & $3,3 \pm 0,6$ & $3,3 \pm 0,5$ & $4,3 \pm 0,6$ \\
\hline \multirow{2}{*}{$\begin{array}{c}\text { Shuttle running } \\
10 / 10 \mathrm{~m}\end{array}$} & result & $26,1 \pm 1,1$ & $26,9 \pm 1,3$ & $27,5 \pm 1,5$ & $29,9 \pm 2,4$ & $29,9 \pm 3,7$ & $34,5 \pm 5,5$ \\
\hline & mark & $3,6 \pm 0,7$ & $3,7 \pm 0,9$ & $4,7 \pm 0,7$ & $4,5 \pm 0,7$ & $4,6 \pm 0,5$ & $4,7 \pm 0,6$ \\
\hline \multirow{2}{*}{$\mathrm{CPE}$} & result & $12,7 \pm 4,3$ & $11,7 \pm 4,2$ & $10,1 \pm 3,4$ & $8,1 \pm 2,9$ & $7,2 \pm 1,5$ & $5,7 \pm 1,15$ \\
\hline & mark & $3,37 \pm 1,1$ & $3,18 \pm 0,9$ & $3,5 \pm 1,08$ & $3,6 \pm 1,08$ & $4,0 \pm 0,8$ & $4,3 \pm 0,6$ \\
\hline $\begin{array}{c}\text { The skills } \\
\text { of fighting } \\
\text { techniques use }\end{array}$ & mark & $3,4 \pm 0,6$ & $3,5 \pm 0,7$ & $3,5 \pm 0,7$ & $3,5 \pm 0,6$ & $3,7 \pm 0,7$ & $4,0 \pm 0$ \\
\hline
\end{tabular}

The mentioned reasons, in our opinion, are conditioned, first of all by the contradictions between modern demands of normative documents claimed on the level of physical, functional and psychological readiness of Russia FPC special convoy units members and insufficient methodical support of the existing system of professionalapplied physical training.

It is possible to get rid of the mentioned contradiction by means of creating and substantiation of Russia FPC special convoy units members professional-applied physical training experimental methodology, based on the use of intensive psycho-functional training means.

\section{CONCLUSION}

The results of the held research prove the satisfying level of physical training in Russia FPC special convoy units members in Perm region, which drives us at the conclusion about a low effectiveness of their professional-applied physical training system.

In order to increase the effectiveness of professional-applied physical training among the members of special convoy units it is necessary to realize the search for new scientifically substantiated methodologies, including those, based on the use of intensive psycho-functional training means.

\section{REFERENCES}

1.The decree of the Minister of Russia 12.11.2001 № 301 "On adopting Physical training Manual among the members of Penal Enforcement system of the Minister of Russia”. URL: https:// ukrfkod.ru/zakonodatelstvo/prikaz-miniustarossii-ot-12112001-n-301

2. Akimova K.K., Kolevatov A.V. The question of physical training organization among the members of Penal Enforcement system of the Russian Federation and Internal Affairs Agencies of the Russian Federation, positive experience of physical fitness control among military men of the Russian Federation Ministry of Defense. Gumanitarnye nauchnye issledovaniya. 2019; 6. URL: http://human.snauka.ru/2019/06/25937 (In Russ.)

1. Zezyulin F.M. Fizicheskaya podgotovka sotrudnikov ugolovno-ispolnitel'noj sistemy: monografiya [Physical training of the members of Penal Enforcement System: monograph]. Federal 
Penitentiary Service, Vladimir Juridical Institute of Federal Penitentiary Service. Vladimir: VJI FPC of Russia publishing house. 2006; 159 (In Russ.).

2. Pozdeeva L. V., Bandakov M.P. The levels of physical, functional and psychological readiness analysis among the members of Penal Enforcement system and the ways of their optimization. Vestnik VyatSU. 2012; №1-3: 66-71 (In Russ.).

3. Anderson C.B., Hagstromer M., Yngve A. Validation of the PDPAR as an adolescent diary: Effect of accelerometer cut points. Medicine and Science in Sports and Exercise. 2005; 37: 12241230.

4. Brage S., Wedderkopp N., Franks P.W., Andersen L.B., Froberg K. Reexamination of validity and reliability of CSA monitor in walking and running. Medicine and Science in Sports and Exercise. 2003; 35: 1447-1454.

5. Craig C.L., Marshall A.L., Sjostrom M., Bauman A.E., Booth M.L., Ainsworth B.E., et al. International physical activity questionnaire: 12-country reliability and validity. Medicine and Sciences in Sports and Exercise. 2003; 35: 1381-
1395 .

6. Mader U., Martin B.W., Schutz Y., Marti B. Validity of four short physical activity questionnaires in middle-aged persons. Medicine and Science in Sports and Exercise. 2006; 38: 12551266.

7. Nokhrin M.Y. Peculiarities of a penal executive system member training for close fight with a criminal in water. Pedagogiko-psychologicheskie I medico-biologicheskie problemy fizicheskoj kul'tury I sporta = Pedagogico-psychological and medicobiological problems of physical culture and sport. 2014; 9(1): 107-114. DOI: 10.14526/25_2014_25 (In Russ., In Engl.).

8. Zheleznyakova A.G., Pankrat'eva O.G., Baranov A.F. The first - year students' level of physical readiness evaluation on the example of the kursk state agricultural academy. Pedagogikopsychologicheskie I medico-biologicheskie problemy fizicheskoj kul'tury I sporta = Pedagogicopsychological and medico-biological problems of physical culture and sport. 2014; 9(1): 33-39. DOI: 10.14526/15_2014_15 (In Russ., In Engl.).

\section{Submitted: 10.11.2019}

\section{Author's information:}

Pavel S. Sokolov - Lecturer, Perm Institute of Federal Penitentiary Service, 614012, Russia, Perm, Karpinskogo str., House 125, e-mail: pavel.sokolov.14@mail.ru

Tatyana V. Fendel - Candidate of Pedagogics, Associate Professor, Chaykovskiy State Institute of Physical Culture ,617764, Russia, Chaykovski, Lenina str., House 67, e-mail:fendel82@mail.ru 